\title{
A Syllabus Design of College Integrated English Class in China----On the Integration of Task-based Teaching and Classroom-based Assessment
}

\author{
Cui Zheng \\ School of International Exchanges, Shandong Normal University \\ 250014, 88 East Wenhua Road, Jinan, Shandong, China \\ Tel: 86-531-86182860 E-mail: zhengcui001ruth@163.com
}

Received: 22-06-2013

doi:10.7575/aiac.ijalel.v.2n.6p.36
Accepted: 01-08-2013

Published: 01-11-2013

URL: http://dx.doi.org/10.7575/aiac.ijalel.v.2n.6p.36

The research is financed by Chinese Foreign Language Education Fund (中国外语教育基金). No. ZGWYJYJJ $2012 A 02$.

\begin{abstract}
The national College English Curriculum Requirements in China focus on college students' overall English ability, students' self-learning ability and teachers' objective assessment towards students as well. This paper thus designed a syllabus for college Integrated English class based on syllabus design standard by Nunan, task-based language teaching theory by Ellis and the classroom-based assessment theory by Gottlieb and Brown and Abeywickrama. Task-based teaching and classroom-based assessment both emphasize the importance of student-centered and student-involved tasks and the overall assessment of students' performance. This syllabus thus combined these theories, designed tasks such as in-class quick shares, textbook lecturing, social interviews and reports, written reflections of each textbook article etc. and tries to assess students' performance through both formative and summative ways such as peer and self assessment through the evaluating rubrics of these tasks, portfolios, and final examinations. The implementation will finally test the effectiveness and efficiency of this syllabus.
\end{abstract}

Keywords: College English Curriculum Requirements, syllabus design, task-based teaching, classroom-based assessment

\section{Introduction}

English is regarded as the most widely used language in the world (Mydans, 2007). How is it taught in colleges and universities in China? How to teach and learn it more effectively in current China? Lam (2002) overviewed the language policy changes in China and claimed that since 1991 most Chinese people are learning English for international stature. Adamson (2004) holds the similar opinion, who claimed that China's Open Door Policy made the status and role of English in China more popularized. Based on her investigation, Lam (2005) pointed out that English has been the most important foreign language in China since the late 1950s. Now in China, almost every university or college has the English department. Every college student needs to pass CET-4 (Note 1) (Band 4 of College English Test, a national standardized English test in China) in order to graduate.

The national guidance of college English teaching and learning in China is called "College English Curriculum Requirements" issued by the national Ministry of Education (Note 2). The newest version of the national College English Curriculum Requirements (CECR for short) in China was issued in 2007, which covers teaching objectives, teaching requirement, course design, teaching model, teaching assessment, and teaching management. It claimed that in view of the different teaching resources, student enrollment and different social needs in different colleges and universities, this national curriculum should be regarded as a reference, and each college and university should have their English teaching syllabus based on their own actual situation.

According to CECR, English is a compulsory and fundamental course in college and university. The goal of college English teaching is to develop students' English proficiency, especially listening and speaking skills, in order to enhance their English communication ability in the future, while improving their self-learning ability as well. From CECR, it could be inferred that 1) English is very important for college students in China. 2) English listening, speaking and communication skills are especially important when teaching and learning English in Chinese background. 3) Students' self-learning ability should also be cultivated and improved. CECR also mentioned that formative and summative assessment should both be adopted. Formative assessment such as in-class observation, portfolio, and interviews should be widely used besides the summative assessment, which is mainly the final examination. However, what CECR doesn't mention is what to teach in English class. Shu (2010) claimed that language is the media to learn other knowledge. Through English, students can learn some topic knowledge. It is good not only to stimulate students' 
interest and enthusiasm, and also good to improve students' overall quality. Therefore, in English class, topic knowledge could also be learned.

Based on CECR, since English attaches so important role to college students in China, these questions arise: 1) How to enhance students' listening, speaking and communicative ability? 2) How to enhance students' self-learning ability? 3) What to teach in English class? 4) How to assess students more effectively? This paper is intended to design a syllabus for college integrated English class, trying to solve the above-mentioned questions. The theories adopted in this research are the task-based teaching method and the classroom-based assessment.

\section{Related Theories}

\subsection{Syllabus Design}

According to Nunan (1988), syllabus is "a specification of what is to be taught in a language program and the order in which it is to be taught. A syllabus may contain all or any of the following: phonology, grammar, functions, notions, topics, themes, tasks" (p. 159). Based on Nunan's definition, it can be inferred that when designing a syllabus, the teaching goal and teaching methods should be clearly included in the syllabus. Besides, topics or tasks can also be included in it. Nunan further distinguished the difference between syllabus and curriculum. He claimed that curriculum is "principles and procedures for the planning, implementation, evaluation, and management of an educational program" (p.158). Curriculum study "embraces syllabus design (the selection and grading of content) and methodology (the selection of learning tasks and activities)" (p.158). Therefore, we can say that CECR is the guidance, which embraces the specific syllabus design for college integrated English class. Meanwhile, when this specific syllabus is designed, as mentioned, the teaching goals, teaching content, tasks and activities, the assessment method as well, should be clearly stated in it.

\subsection{Task-based Language Teaching}

Task-based language teaching (TBLT) is a very heated issue over the past 30 years in the field of second language acquisition and learning (Robinson, 2011). Many researches have made contributions on TBLT (e.g. Nunan, 1989; Byrnes, 2002; Seedhouse, 2005). Bachman and Palmer (1996) defined a "language use task" as "an activity that involves individuals in using language for the purpose of achieving a particular goal or objective in a particular situation" (p. 44). Ellis (2003) defined tasks as "activities that call for primarily meaning-focused language use" (p.3). No matter how they define what a task is, these researchers reached a consensus, i.e. TBLT is effective for learners to learn a second or foreign language. Bourke (2006) designed a topic-based syllabus for younger learners. He claimed that the reason why he designed a topic-based/task-based syllabus is based on the belief that children learn best by doing meaningful tasks in a stress-free and supportive learning environment. Byrnes (2002) listed several advantages of doing task-based assessment, such as learners could learn language and content/knowledge at the same time.

How to design task-based lessons? Ellis (2003) designed a framework for designing task-based lessons (p. 244). As shown in table 1, task needs to be designed in a very detailed way. Time, frame of the activity, number of participants, etc. all need to be considered well. Tasks in researcher's sample syllabus are designed based on this framework.

Table 1. A framework for designing task-based lessons

\begin{tabular}{ll}
\hline Phase & Examples of options \\
\hline A Pre-task & Framing the activity, e.g. establishing the outcome of the task \\
\cline { 2 - 2 } & Planning time \\
\cline { 2 - 2 } & Doing a similar task \\
\hline B During task & Time pressure \\
\cline { 2 - 2 } & Number of participants \\
\hline C Post-task & Learner report \\
\cline { 2 - 2 } & Consciousness raising \\
\cline { 2 - 2 } & Repeat task \\
\hline
\end{tabular}

\subsection{Classroom-based Assessment}

Classroom-based assessment, based on Gottlieb's (2006) explanation, includes "activities, tasks, and projects embedded in instruction for the primary purpose of monitoring student progress" (pp. 86-86). In other words, activities, tasks, and projects are "the core of classroom assessment" (p.89). Abeywickrama (2011-2012) defined classroom-based assessment as that which includes all activities teachers and students do in classroom in order to teach and learn. She also mentioned that classroom-based assessment is more teacher-mediated, student-involved, context-based and learning-focused. Besides, she made it clear that classroom-based assessment, teacher-based assessment, school-based assessment, formative assessment and alternative assessment can be used interchangeably to refer to the same classroom-based assessment. Brown and Abeywickrama (2011) distinguished the terms alternative assessment, taskbased assessment and performance assessment. According to them, task-based assessment is a subset of performance assessment, whereas performance assessment is one primary "trait" (p.127) of alternative assessment. In a word, classroom-based assessment should involve all the activities, tasks and projects students participate and assess them in a formative way. In other words, assessment should be more for learning rather than of learning. 


\section{Syllabus Design for Integrated English Class}

This study tries to design a tentative syllabus for the college Integrated English class based on the above-mentioned syllabus design standard, task-based teaching and classroom-based assessment. This syllabus tries to combine the tasks/activities and the formative assessment into one, and conduct the class with students as the center. Therefore, some tasks such the social interview, in-class quick shares, lecturing of each unit and reflections of each unit are designed. Students are supposed to finish these tasks with group members or independently. Besides, since the targeted undergraduate students are majoring in teaching Chinese to foreigners, the content of the in-class quick shares should relate to Chinese or western cultures; the interviewee of their social interviews should also be the foreign students who can speak good English. In view of the assessment method, this syllabus tries to combine both formative and summative assessing methods. Besides the traditional final exams, portfolios, self-assessment and peer assessment are also included as factors of the students' final scores. All the class activities have a comparatively objective rubric as the standard to assess students' performance. This tentative syllabus is as follows:

\subsection{Course Description-Integrated English (3)}

The textbook used for this course is named "An Integrated English Course (Book 3)", published by Shanghai Foreign Language Education Press in 2011. The chief editor is He Zhaoxiong. Students are all sophomores, majoring in teaching Chinese as a foreign language. Through this course, students are supposed to learn eight units of the textbook, including the related cultural background, intensive article reading, grammar, vocabulary, translation, listening and speaking exercises etc.

\subsection{Course Objectives}

Students' English listening, speaking, writing, reading and translating ability, especially listening, speaking and writing abilities will be improved in a comprehensive way after the exposure to English for a whole semester.

1. Learn how to make speech.

2. Learn how to do the in-class presentation.

3. Learn how to work in teams to do the social interview.

4. Learn how to write social research report.

5. Learn how to analyze reading materials.

6. Learn the usage of more words and expression.

\subsection{Assignments and Projects}

\subsubsection{In-class Quick Shares (Individual)}

A quick share is simply a single brief instruction of any sparkles of Chinese culture or western class. As majoring in teaching Chinese as a foreign language, students should know how to introduce Chinese culture to others in English, or they should be familiar with other cultures. Each class session, one or two class members will present a quick share at the beginning of the class. Before the class, PPT should be installed into the classroom computer or handout should be provided. Students should explain what this cultural sparkle is and why it is special in one culture. Students should finish the quick share within 5 minutes. Quick share should also be included in the portfolio. (5 points)

Table 2. Rubric for Quick Shares

\begin{tabular}{lllll}
\hline Objective & Performance Indicators (5 points in total) & \\
\cline { 2 - 6 } /criteria & Excellent (2 points) & Acceptable (1points) & Unacceptable (0 points) \\
\hline Prepared & $\begin{array}{l}\text { Student is fully prepared } \\
\text { (2 points) }\end{array}$ & $\begin{array}{l}\text { Student is partially } \\
\text { prepared (1points) }\end{array}$ & Student is not prepared (0 points) \\
\hline Content & $\begin{array}{l}\text { Content is successfully } \\
\text { delivered (2 points) }\end{array}$ & $\begin{array}{l}\text { Content is delivered in a } \\
\text { good way (1 points) }\end{array}$ & Content is not well delivered (0 points) \\
\hline Timing & $\begin{array}{l}\text { Students arrive on time for the presentation; } \\
\text { completes presentation within the allotted time } \\
(2 \text { points) }\end{array}$ & $\begin{array}{l}\text { Students arrive several minutes later for } \\
\text { presentation; presentation is much too short or too } \\
\text { long. (0 points) }\end{array}$ \\
\hline
\end{tabular}

\subsubsection{Lecturing of Articles in Each Unit (Group work)}

Basically there is only one main article in each unit. As future Chinese teachers, students need to learn how to teach clearly and logically. Four or five students are going to work together as a group. Students need to explain the whole article to the whole class, including the cultural background, how to warm up, how to lead in to the article, the structure of the article, the language points in each paragraph, the difficult sentences, and the exercise after the article. Basically, students, as a group, need to cover every detail of the unit. Students need to behave as a teacher and try to deliver the lesson as successfully as they can. Before the class, each group needs to assign the tasks to each group member, and each of group members need to do the presentation. Each student's score is single presentation plus group's total behavior. Each group may need two hours to finish the lecturing. All presentations need to be printed out at the end of the semester and put into the portfolio. (15 points) 
Table 3. Rubric for in-class article lecture

\begin{tabular}{|c|c|c|c|}
\hline \multirow{2}{*}{$\begin{array}{l}\text { Objective } \\
\text { /criteria }\end{array}$} & \multicolumn{3}{|l|}{ Performance Indicators ( 15 points in total) } \\
\hline & Excellent & Acceptable & Unacceptable \\
\hline Prepared & $\begin{array}{l}\text { Student is fully prepared }(4-5 \\
\text { points) }\end{array}$ & $\begin{array}{l}\text { Student is partially } \\
\text { prepared (2-3points) }\end{array}$ & $\begin{array}{l}\text { Student is not prepared } \\
(0-1 \text { points })\end{array}$ \\
\hline $\begin{array}{l}\text { Article } \\
\text { content }\end{array}$ & $\begin{array}{l}\text { Content is successfully delivered, } \\
\text { with grammar and vocabulary and } \\
\text { paragraph meaning fully and clearly } \\
\text { explained ( } 5-6 \text { points) }\end{array}$ & $\begin{array}{l}\text { Content is delivered in a } \\
\text { good way, with most } \\
\text { content explained }(3-4 \\
\text { points) }\end{array}$ & $\begin{array}{l}\text { Content is not well delivered (0-2 } \\
\text { points) }\end{array}$ \\
\hline $\begin{array}{l}\text { Group } \\
\text { coordination }\end{array}$ & $\begin{array}{l}\text { The group has coordinated } \\
\text { presentation well and everything fits } \\
\text { together. ( } 2 \text { points) }\end{array}$ & $\begin{array}{l}\text { The group was somewhat } \\
\text { coordinated, and some } \\
\text { things fits together. (1 } \\
\text { points) }\end{array}$ & $\begin{array}{l}\text { The group failed to coordinate. ( } 0 \\
\text { points) }\end{array}$ \\
\hline Timing & $\begin{array}{l}\text { Students arrive on time for the } \\
\text { presentation within the allotted time } \\
(2 \text { points) }\end{array}$ & presentation; completes & $\begin{array}{l}\text { Students arrive several minutes } \\
\text { later for presentation; } \\
\text { presentation is much too short or } \\
\text { too long. ( } 0 \text { points) }\end{array}$ \\
\hline
\end{tabular}

\subsubsection{Social Interview (Group work)}

This activity mainly intends to improve students' English speaking and listening ability. What students are going to do is try to find an English native speaker and do an interview. The interview topic is flexible. Any topic is okay as long as student group and the interviewee both agree to talk on it. Students need to discuss with group members first and have an interview outline before implementing the interview. Each group member needs to speak during the interview and they need to make a video and show it in the class when doing the interview presentation in the class. The interview lasts about 15 minutes. So your in-class interview presentation lasts about 20 minutes. After the interview, each group needs to write an interview report, including the transcription of the conversation, reflections of the interview, etc. Again, the report needs to be printed out and put in the portfolio. As students in the School of International Exchanges, it is not very hard to find an interviewee who speaks English. (10 points).

Table 4. Rubric for sccial interview

\begin{tabular}{|c|c|c|}
\hline \multirow{2}{*}{$\begin{array}{l}\text { Objective } \\
\text { /criteria }\end{array}$} & \multicolumn{2}{|l|}{ Performance Indicators (10 points in total) } \\
\hline & Acceptable & Unacceptable \\
\hline Report & $\begin{array}{ll}\text { Interview transcription is well } & \text { Interview transcription is } \\
\text { done. Report is well written. } & \text { done mostly well. Report is } \\
\text { (3-4 points) } & \text { written in a good way. } \\
& (2 \text { points })\end{array}$ & $\begin{array}{l}\text { No or poor transcription, with no or } \\
\text { poor report. ( } 0-1 \text { points) }\end{array}$ \\
\hline $\begin{array}{l}\text { Presentation } \\
\text { Prepared }\end{array}$ & $\begin{array}{l}\begin{array}{l}\text { Student is fully prepared (2 } \\
\text { points) }\end{array} \\
\text { Student is partially prepared } \\
\text { (1points) }\end{array}$ & Stud \\
\hline $\begin{array}{l}\text { Oral } \\
\text { presentation }\end{array}$ & $\begin{array}{l}\text { Excellent overview of the whole social interview process } \\
\text { (1points) }\end{array}$ & $\begin{array}{l}\text { Inadequate overview of the whole } \\
\text { social interview process. ( } 0 \text { points) }\end{array}$ \\
\hline $\begin{array}{l}\text { Group } \\
\text { coordination }\end{array}$ & $\begin{array}{l}\text { The group has coordinated } \\
\text { presentation group was somewhat } \\
\text { everything fits together. ( } 2 \text { fits together. ( } 1 \text { points) } \\
\text { points) }\end{array}$ & $\begin{array}{l}\text { The group failed to coordinate. }(0 \\
\text { points) }\end{array}$ \\
\hline Timing & $\begin{array}{l}\text { Students arrive on time for the presentation; completes } \\
\text { presentation within the allotted time } \\
\text { (1 points) }\end{array}$ & $\begin{array}{l}\text { Students arrive several minutes later } \\
\text { for presentation; presentation is } \\
\text { much too short or too long. (0 } \\
\text { points) }\end{array}$ \\
\hline
\end{tabular}

\subsubsection{Reflections of Each Unit (Individual)}

This task mainly intends to practice students' English writing. After learning each unit, students are supposed to write a reflection based on what they have learned. Students may like to write something related to their own life, or they may like to express their own opinion towards what the article said in each unit, or they may just like to discuss something on a language point, whatever is okay. At least one page is needed, 12 font, 1.5 space. They are suggested to type it out because all the eight reflections will be put into the portfolio at the end of the semester. ( 2 points for each* $8=16$ points) 


\begin{tabular}{lll}
\hline Performance Indicators (2 points in total) & & \\
\hline Excellent & Acceptable & Unacceptable \\
\hline Reflection essay is very well written, with & Essay is written in a good way, except & Essay is too short, or with \\
meaningful content, correct grammar and for a few grammar or vocabulary & some avoidable mistakes. (0 \\
vocabulary, good logic and enough words. & $\begin{array}{l}\text { mistakes, or unclear logic. } \\
\text { ( } 2 \text { points) }\end{array}$ & points $)$ \\
\hline
\end{tabular}

\subsubsection{Final Exam (Individual)}

The final exam would be the exam implemented by the university. It is going to be an overall review of what students have learned for the whole semester. Vocabulary, grammar, reading, writing and translation would be included. 3.3.6 Portfolio (Individual)

One end product of this course will be a portfolio containing items described above. The portfolio is essentially a collection of students' completed assignments organized in a neat and professional manner. The portfolio will be a valuable witness for what students will have done for the whole semester. (4 points)

Portfolio contents: Culture quick share/Lecturing of each unit article /Social interview report/Reflections of each unit (eight essays in total).In addition, the portfolio must: Be neatly hole-punched and secured within a paper-based portfolio cover/Include a table of contents/Include section labels/Have contents in the order listed above.

Table 6. Rubric for porfolio

\begin{tabular}{ll}
\hline Points & Requirements \\
\hline 4 points & All required items included \\
& Each item is complete \\
& Neatly organized \\
\hline $2-3$ points & $\begin{array}{l}\text { Some items may be missing } \\
\text { Some items may be incomplete } \\
\\
\text { Not very neatly organized }\end{array}$ \\
\hline $0-1$ points & $\begin{array}{l}\text { No portfolio } \\
\text { Nearly all items are missing or incomplete }\end{array}$ \\
\hline
\end{tabular}

\subsection{Grading System}

Table 7 shows the whole grading system. The summative final exam consists of only $40 \%$, whereas all the other $60 \%$ is about the formative assessment.

Table 7. Grading system

\begin{tabular}{ll}
\hline Grading sessions & Points \\
\hline Attendance & 10 points \\
\hline Quick share & 5 points \\
\hline Lecturing of each unit article & 15 points \\
\hline Social interview & 10 points \\
\hline Reflections of each unit & 16 points \\
\hline Final exam & 40 points \\
\hline Portfolio & 4 points \\
\hline Total & 100 points \\
\hline
\end{tabular}

\section{Discussions and Conclusion}

When designing this syllabus, I kept fours standards in my minds: 1) This syllabus must have a very clear goal and content. 2) This syllabus must emphasize on students-centered activities, to stimulate students' learning passion and creative ability. 3) Assessment methods must be formative and objective, and truly reflect students' performance and progress. The syllabus clearly states that students can improve their English listening, speaking, writing, and reading skill through a series of activities. To be specific, their speech-making ability, social communicative ability, article analyzing ability, cooperative ability, writing ability etc. could be improved. The designed activities are varied, either needing independent or team work. When designing each task, details are described in the syllabus. For example, when designing the social interview, students are required to write an outline of their interviews questions, discuss first before doing the real interview, taking videos during the interview, and doing the written and oral report after the interview, and reflections of the interview as well. Through this whole process, students can definitely learn a lot not only the language skills, but also the specific knowledge in some field. Another task is that students are required to lecture the class as a group. Through the preparation of how to explain the article, how to deal with the teaching procedure, how to make PPT, how to work together, and throught the discucsion of langaugae points and article sturcutre and so on, I am sure that they will benefit a lot. Assessment method is also varied and effective. Each activity is evaluated through the rubric. Besides, portfolios, and final examination is also necessary for assessing students. It is a good combination of 
both formative and summative assessment to students' performance. Therefore, the grading system can be very valid and reliable. In addition, at the beginning of the class, it should be clearly claimed to students that this course does not rely on the traditional mid-terms and final exams. Most of the learning takes place in class during interactive lectures, demonstrations, discussions, and cooperative learning. Thus, regular attendance and participation is essential and mandatory. Students are responsible for making up any absences. The method for making up the absence should also be clear. Students are supposed to write a one page summary of an article out of the textbook, due the week following the absence as the make-up.

The limitation is that it is a tentative syllabus, so when implementing it, there must be plenty of unexpected problems. Before implementing it, students' needs analysis should also be considered, thus necessary changes in syllabus should be made based on students' needs. What I am going to do is to use this syllabus in my class and try to find out the problems, solve them, and make the class more effective and efficient. Besides, when implementing it, teachers' scaffolding function can not be ignored. Although this syllabus focuses on students-centered method, English teachers still need to help students when they need help in fulfilling their tasks.

\section{References}

Abeywickrama, P. (2011-2012). Rethinking traditional assessment concepts in classroom-based assessment. The CATESOL Journal, 23(1), 205-214.

Adamson, B. (2004). China's English: a history of English in Chinese Education. Hong Kong: Hong Kong University Press.

Bachman, L. F., \& Palm, A.S. (1996). Language testing in practice: designing and developing useful language tests. Oxford: Oxford University Press.

Bourke, J. M. (2006). Designing a topic-based syllabus for young learners. ELT Journal, 60 (3), $279-286$. http://dx.doi.org/10.1093/elt/ccl008

Brown, H. D., \& Abeywickrama, P. (2011). Language assessment: principles and classroom practice (2nd). New York: Longman.

Byrnes, H. (2002). The role of task and task-based assessment in a content-oriented collegiate foreign language curriculum. Language Testing, 19 (4), 419-437. http://dx.doi.org/10.1191/02655322021t238oa

Ellis, R. (2003). Task-based language learning and teaching. Oxford: Oxford University Press.

Gottlieb, M. (2006). Assessing English language learners: Bridges from language proficiency to academic achievement. Thousand Oaks, CA: Corwin Press.

Lam, A. (2002). English in education in China: Policy changes and learners' experiences. World English, 21 (2), 245

256. http://dx.doi.org/10.1111/1467-971X.00245

Lam, A. (2005). Language education in China: policy and experience from 1949. Hong Kong: Hong Kong University Press.

Mydans, S. (2007, May 14) Across cultures, English is the word. New York Times. Retrieved from http://www.nytimes.com/2007/04/09/world/asia/09iht-englede.1.5198685.html?pagewanted=all\&_r=0

Nunan, D. (1988). Syllabus design. Oxford: Oxford University Press.

Nunan, D. (1989). Designing tasks for the communicative classroom. Cambridge: Cambridge University Press.

Robinson, P. (2011). Task-based language learning: A review of issues. Language Learning, 61, 1-36. http://dx.doi.org/10.1111/j.1467-9922.2011.00641.x

Seedhouse, P. (2005). “Task” as research construct. Language Learning, 55, 533-570. http://dx.doi.org/10.1111/j.0023

8333.2005.00314.x

Shu, D, F. (2010). What to teach and how to teach in the college English class. Foreign Language World, 6, $26-32$.

\section{Notes}

Note 1. The website of College English Test in China: http://www.cet.edu.cn/ (accessed 06/19/2013)

Note 2. The website of Chinese Ministry of Education which issued College English Curriculum Requirements: http://www.moe.gov.cn/publicfiles/business/htmlfiles/moe/s3857/201011/xxgk_110825.html (accessed 06/15/2013) 